\title{
Recent advances in pruritus - what we have learned and where are we headed
}

\section{Gil Yosipovitch}

Address: Department of Dermatology, Wake Forest University Health Sciences, Medical Center Boulevard, Winston-Salem, NC 27157, USA

Email: gyosipov@wfubmc.edu

Fl000 Medicine Reports 2010, 2:39 (doi:10.3410/M2-39)

The electronic version of this article is the complete one and can be found at: http://fl000.com/reports/medicine/content/2/39

\begin{abstract}
Chronic pruritus is an emerging health problem with a significant impact on quality of life. Recent advances in our understanding of newly discovered pathways and receptors for itch have been made. It is hoped that recent advancements will also drive the development of novel therapies for this oftenneglected and bothersome symptom.
\end{abstract}

\section{Introduction and context}

Pruritus is a common symptom that has multifactorial etiologies that range from skin to neural and systemic diseases, and its pathophysiology has been, until recently, poorly understood. Epidemiological studies have shown that it is common in $8-12 \%$ of the general population [1]. Chronic pruritus has a profound impact on quality of life by disturbing sleep and affecting attention. A large study has shown that hemodialysis patients who itch have a higher mortality risk, which is related to their lack of sleep [2].

\section{Recent advances}

A specific separate pathway for histamine-induced itch was found more than a decade ago in a subset of $\mathrm{C}$ nerve fibers in humans and later in spinal projection neurons of cats $[3,4]$. In 2007, investigators discovered a separate parallel itch processing pathway activated by cowhage spicules (Mucuna pruriens), which revealed an activation of peripheral nerve fibers in humans as well as specific spinal projection neurons in primates [5-7]. However, these C fiber afferents are not itch-specific since they are also activated by heat stimuli that induce the sensation of pain. Cowhage is also known to induce a burning sensation along with itch. The active ingredient in cowhage has been isolated as a cysteine protease (mucunanin) that activates proteinase-activated receptor 2 (PAR2) and PAR4 [8] in nerve fibers and keratinocytes. PAR2 receptors and their ligands, serine proteases, have previously been demonstrated to have a significant role in the itch associated with atopic eczema [9]. Recently, cathepsin S, an endogenous cysteine protease secreted by keratinocytes, was found to induce itch [10]. This finding suggests that cathepsin S may have a role as an itch mediator in inflammatory skin diseases.

New evidence for a specific pathway for itch was generated by the findings of neurons expressing a gastrin-releasing peptide receptor (GRPR) gene that transmit only itch and not pain [11]. GRPR is a G protein-coupled receptor for gastrin-releasing peptide (GRP), a bombesin-like peptide that is widely distributed in the gastrointestinal tract and central nervous system. Moreover, in a model of chronic itch and atopic dermatitis-like skin lesions in mice, the mice pretreated with a GRPR antagonist presented no scratching [12]. The role of this receptor in humans and in atopic eczema remains to be defined.

The common view is that the epidermis may act as a receptor for itch, but a specific receptor has not yet been clearly identified. Recent studies provide evidence that, indeed, there are itch-specific receptors in the skin. A subset of $\mathrm{C}$ nerve fibers that contain MRGPRA (Masrelated $\mathrm{G}$ protein-coupled receptor member A), a subfamily of $G$ protein-coupled receptors, were found to 
mediate itch sensation induced by chloroquine [13]. Chloroquine is an antimalarial drug that is known to induce itch in humans, especially in those with dark skin color (Africans). These neurons did respond to histamine and capsaicin (these cells had also expressed GRP, the ligand for GRPR) as well as to histamine, providing evidence that these cells play an important role in pruritus. Another recent discovery of a possible itch receptor in humans was found in lichen amyloidosis, a localized form of severe itch common in Asians and Hispanics. A mutation in the oncostatin $M$ receptor (OSMR) gene, which encodes OSMR-beta, an interleukin-31 (IL-31) cytokine receptor, was found in these patients [14]. IL-31 (a Th2 cell-derived cytokine) was previously found to elicit itch in atopic dermatitis and prurigo nodularis [15]. An IL31 antibody effectively reduced scratching behavior in an atopic dermatitis-like murine model, suggesting the potential therapeutic role of IL-31 antibody in the treatment of chronic itch [16].

The concept of pruritic mediators that act centrally and peripherally is becoming more widely recognized. Among the long list of mediators, opioids have a major role in generalized pruritus. It has been known for decades that analgesia obtained with mu opioids induces itch, most probably via reduction of inhibition of pain fibers, whereas mu antagonists, such as naltrexone, inhibit itch. It has been suggested that chronic itch is associated with an imbalance between mu and kappa opioid systems [17]. This effect is not limited to the central nervous system but also occurs in the skin as demonstrated in keratinocytes of patients with atopic eczema [18]. This latter finding led to the development of a novel kappa opioid receptor agonist. Recent results of a phase III, double-blind study in chronic kidney disease-associated pruritus showed that orally taken nalfurafine effectively reduced itch [19]. Of note, nalfurafine was officially approved for clinical use as an antipruritic for chronic kidney disease-associated pruritus in Japan last year.

Chronic pruritus shares many similarities, including peripheral and central sensitization, with chronic pain [20]. Therefore, many endogenous inflammatory mediators that are involved in chronic pain via sensitization of nociceptive nerve fibers such as prostanoids, serotonin, nerve growth factor, and transient receptor potential vanilloids (TRPVs) also have a role in chronic pruritus [21]. TRPV1 and TRPV3 have recently been implicated in the pathogenesis of pruritus $[22,23]$. These observations taken together may suggest that TRPV1 is a relay through which capsaicin exerts its antipruritic effect. Beneficial effects of capsaicin have been reported in chronic, localized pruritic disorders, particularly those of neuropathic origin. Substance $\mathrm{P}$ is a neuropeptide widely distributed in peripheral nerve fibers and the central nervous system and is known to intensify itch perception. A recent study in rats demonstrated that the destruction of substance P receptor neurokinin 1-expressing neurons in the spinal dorsal horn significantly attenuated scratching response [24]. These results suggest that substance P and its neurokinin receptor 1 have a role as itch transmitters in the central nervous system [24].

The existence of central nerve sensitization is demonstrated by studies in chronic itch patients who perceive painful stimuli as itching [21]. Moreover, robust activation in the brain in areas involved in central sensitization has been noted in chronic itch [25]. This explains the rationale of using neuroleptics and antidepressants in the treatment of chronic pruritus [26]. The exact mechanisms, as well as the magnitude of their beneficial effects, remain largely unclear.

\section{Implications for clinical practice}

It is time to re-think the current itch treatment strategy that mainly includes topical corticosteroids and oral antihistamines that have limited effect in most types of chronic pruritus. At present, clinical management of chronic pruritus should include the use of drugs that reduce neuronal sensitization for pain (such as gabapentin) and pregabalin and selective serotonin and neuroepinpherine antidepressants, either as monotherapies or in combination. Hopefully, in the future, we will see a wide range of topical and systemic therapies that target the various receptors and neural pathways that mediate itch of different types and lead to improved quality of life for millions of pruritic patients.

\section{Abbreviations}

GRP, gastrin-releasing peptide; GRPR, gastrin-releasing peptide receptor; IL-31, interleukin-31; OSMR, oncostatin $M$ receptor; PAR, proteinase-activated receptor; TRPV, transient receptor potential vanilloid.

\section{Competing interest}

The author declares that he has no competing interests.

\section{Acknowledgments}

The author is supported by a National Institutes of Health (NIH) grant (1R01AR055902-01A1).

\section{References}

I. Weisshaar E, Dalgard F: Epidemiology of itch: adding to the burden of skin morbidity. Acta Derm Venereol 2009, 89:339-50.

2. Pisoni RL, Wikström B, Elder SJ, Akizawa T, Asano Y, Keen ML, Saran R, Mendelssohn DC, Young EW, Port FK: Pruritus in haemodialysis patients: international results from the Dialysis Outcomes and Practice Patterns Study (DOPPS). Nephrol Dial Transplant 2006, 2 I:3495-505. 
3. Schmelz M, Schmidt R, Bickel A, Handwerker HO, Torebjörk HE: Specific C-receptors for itch in human skin. J Neurosci 1997 , | 7:8003-8.

4. Andrew D, Craig AD: Spinothalamic lamina I neurons selectively sensitive to histamine: a central neural pathway for itch. Nat Neurosci 200I, 4:72-7.

5. Johanek LM, Meyer RA, Friedman RM, Greenquist KW, Shim B, Borzan J, Hartke T, LaMotte RH, Ringkamp M: A role for polymodal C-fiber afferents in nonhistaminergic itch. J Neurosci 2008, 28:7659-69.

6. Davidson S, Zhang X, Yoon CH, Khasabov SG, Simone DA, Giesler GJ Jr: The itch-producing agents histamine and cowhage activate separate populations of primate spinothalamic tract neurons. J Neurosci 2007, 27:10007-14.

FI000 Factor 3.0 Recommended

Evaluated by Gil Yosipovitch 08 Jan 2008

7. Namer B, Carr R, Johanek LM, Schmelz M, Handwerker HO, Ringkamp M: Separate peripheral pathways for pruritus in man. J Neurophysiol 2008, I 00:2062-9.

8. Reddy B: Cowhage-evoked itch is mediated by a novel cysteine protease: a ligand of protease-activated receptors. J Neurosci 2008, 28:4331-5

FI000 Factor 6.0 Must Read

Evaluated by Gil Yosipovitch 16 Jun 2008

9. Steinhoff M, Neisius U, Ikoma A, Fartasch M, Heyer G, Skov PS, Luger TA, Schmelz M: Proteinase-activated receptor-2 mediates itch: a novel pathway for pruritus in human skin. J Neurosci 2003, 23:6176-80.

10. Reddy VB, Shimada SG, Sikand P, Lamotte RH, Lerner EA: Cathepsin $\mathrm{S}$ elicits itch and signals via protease-activated receptors. J Invest Dermatol 2010, I30:|468-70.

II. Sun YG, Chen ZF: A gastrin-releasing peptide receptor mediates the itch sensation in the spinal cord. Nature 2007, 448:700-3.

FI000 Factor 8.0 Exceptional

Evaluated by Gil Yosipovitch 30 Jul 2007, Ulrich Beuers 12 Sep 2007

12. Sun YG, Zhao ZQ, Meng XL, Yin J, Liu XY, Chen ZF: Cellular basis of itch sensation. Science 2009, 325:|153|-4.

FI000 Factor 8.I Exceptional

Evaluated by Gil Yosipovitch 12 Aug 2009, Marc Jeschke 30 Oct 2009, Matthias Ringkamp 20 Nov 2009

13. Liu Q, Tang Z, Surdenikova L, Kim S, Patel KN, Kim A, Ru F, Guan Y, Weng HJ, Geng Y, Undem BJ, Kollarik M, Chen ZF, Anderson DJ, Dong $X$ : Sensory neuron-specific GPCR Mrgprs are itch receptors mediating chloroquine-induced pruritus. Cell 2009, 139: 1353-65.
14. Tanaka A, Arita K, Lai-Cheong JE, Palisson F, Hide M, McGrath JA: New insight into mechanisms of pruritus from molecular studies on familial primary localized cutaneous amyloidosis. Br J Dermatol 2009, I6 I:1217-24.

15. Sonkoly E, Muller A, Lauerma Al, Pivarcsi A, Soto H, Kemeny L, Alenius H, Dieu-Nosjean MC, Meller S, Rieker J, Steinhoff M, Hoffmann TK, Ruzicka T, Zlotnik A, Homey B: IL-3I: a new link between $\mathbf{T}$ cells and pruritus in atopic skin inflammation. J Allergy Clin Immunol 2006, I I 7:4 I I-7.

16. Grimstad O, Sawanobori Y, Vestergaard C, Bilsborough J, Olsen UB, Grønhøj-Larsen C, Matsushima K: Anti-interleukin-3 I-antibodies ameliorate scratching behaviour in NC/Nga mice: a model of atopic dermatitis. Exp Dermatol 2009, I 8:35-5I.

I7. Kumagai H, Saruta T, Matsukawa S, Utsumi J: Prospects for a novel kappa-opioid receptor agonist, TRK-820, in uremic pruritus. In ltch: Basic Mechanisms and Therapy. Edited by Yosipovitch G, Greaves MW, Fleischer JA, McGlone F. New York: Dekker; 2004: 279-86.

18. Bigliardi PL, Tobin DJ, Gaveriaux-Ruff C, Bigliardi-Qi M: Opioids and the skin-where do we stand? Exp Dermatol 2009, I 8:424-30.

19. Kumagai H, Ebata T, Takamori K, Muramatsu T, Nakamoto $H$, Suzuki H: Effect of a novel kappa-receptor agonist, nalfurafine hydrochloride, on severe itch in $\mathbf{3 3 7}$ haemodialysis patients: a phase III, randomized, double-blind, placebo-controlled study. Nephrol Dial Transplant 2010, 25:125I-7.

20. Yosipovitch G, Carstens E, McGlone F: Chronic itch and chronic pain: analogous mechanisms. Pain 2007, 13 I:4-7.

21. Ikoma A, Steinhoff M, Ständer S, Yosipovitch G, Schmelz M: The neurobiology of itch. Nat Rev Neurosci 2006, 7:535-47.

22. Shim WS, Tak MH, Lee MH, Kim M, Kim M, Koo JY, Lee CH, Kim M, Oh U: TRPVI mediates histamine-induced itching via the activation of phospholipase A2 and I2-lipoxygenase. J Neurosci 2007, 27:2331-7.

23. Imamachi N, Park GH, Lee H, Anderson DJ, Simon MI, Basbaum Al, Han SK: TRPVI-expressing primary afferents generate behavioral responses to pruritogens via multiple mechanisms. Proc Natl Acad Sci U S A 2009, 106:I I330-5.

24. Carstens E, Carstens ML, Simone CT, Jinks S: Dorsal horn neurons expressing NK-I receptors mediate scratching in rats. Neuroreport 2010, 21:303-8.

25. Ishiuji Y, Coghill RC, Patel TS, Oshiro Y, Kraft RA, Yosipovitch G: Distinct patterns of brain activity evoked by histamineinduced itch reveal an association with itch intensity and disease severity in atopic dermatitis. Br J Dermatol 2009, | 6 | : | 072-80.

26. Summey BT Jr, Yosipovitch G: Pharmacologic advances in the systemic treatment of itch. Dermatol Ther 2005, I 8:328-32. 